\title{
Status of the relict population of the Critically Endangered Madagascar spider tortoise Pyxis arachnoides
}

\author{
Ryan C. J. Walker and Tsilavo H. Rafeliarisoa
}

\begin{abstract}
The Madagascar spider tortoise Pyxis arachnoides is endemic to the coastal dry forests of south-west Madagascar. In recent years its range has been reduced by c. $71 \%$, with the species now confined to eight fragmented populations occupying a total of $2,464 \mathrm{~km}^{2}$. These remaining populations are facing a significant threat of extinction because of habitat destruction and other anthropogenic pressures. We developed methodology for a line transect distance sampling survey and applied it systematically across the species' range. The resulting distance model estimated a mean density of 226.9 tortoises $\mathrm{km}^{-2}(95 \%$ confidence interval, CI, 168.1-306.3) and a total population of 664,980 (95\% CI 492,680-897,550). Fragmentation of the species' range suggests the current population could be $<30 \%$ of the historical population. Of the remaining population $73.5 \%$ falls within protected areas. However, nine of these 12 protected areas are designated as IUCN category III, V or VI parks, allowing some extractive activities to be undertaken. The most effective strategy for the conservation of $P$. arachnoides would be to reduce the threats to this species and its habitat, and to develop and expand the current community-based conservation and poverty alleviation programmes in the region.
\end{abstract}

Keywords Chelonia, distance sampling, Madagascar, population density, population size, Pyxis arachnoides

\section{Introduction}

$\mathrm{M}$ adagascar supports one of the highest rates of endemism (Brooks et al., 2006) and, like many other regions of high endemism, has complex patterns of micro-endemism (Goodman \& Benstead, 2005; Wilmé et al., 2006). These patterns of micro-endemism apply to

Ryan C.J. WALKeR* (Corresponding author) Nautilus Ecology, Oak House, Pond Lane, Greetham, Rutland, LE15 7NW, UK. E-mail ryan@nautilusecology. org

Tsilavo H. RafeliarisoA ${ }^{\dagger}$ Département de Biologie Animale, Université d'Antananarivo, Antananarivo, Madagascar

${ }^{*}$ Also at: Department of Environment, Earth and Ecosystems, The Open University, Milton Keynes, UK

$\dagger$ Also at: Madagascar Biodiversity Partnership, Omaha's Henry Doorly Zoo, Grewcock's Center for Conservation and Research, Omaha, Nebraska, USA

Received 30 April 2011. Revision requested 8 June 2011.

Accepted 20 June 2011.
Madagascar's four species of endemic tortoises, all restricted in range and facing threats to their survival from loss of habitat and collection for illegal export to support the pet trade and, in some cases, local consumption (Walker et al., 2004; Leuteritz et al., 2005; Young et al., 2008; Walker, 2010). However, unlike the extensive research on the island's charismatic fauna there has been little research on the ecology and conservation status of Madagascar's tortoises, in particular the smallest genus, Pyxis. This genus comprises two species, the flat-tailed tortoise $P$. planicauda and the spider tortoise $P$. arachnoides, both categorized as Critically Endangered on the IUCN Red List (Leuteritz et al., 2008; Leuteritz \& Walker, 2008).

The study reported here focuses on $P$. arachnoides, a species endemic to the dry coastal forests of south-west Madagascar, where the species occurs only within c. $10 \mathrm{~km}$ of the coast (Walker, 2010; Walker et al., in press). The species historically inhabited a continuous belt of dry forest habitat comprising $555 \mathrm{~km}$ of coastline (Pedrono, 2008), from the Mangoky River to Lac Anony (Bour, 1981; Pedrono, 2008). As a result of habitat destruction (Seddon et al., 2000), collection for international trade and domestic consumption (Walker et al., 2004; Pedrono, 2008; Walker, 2010) the species' range is now fragmented and is thought to have declined by $71 \%$ (Walker, 2010; Walker et al., in press).

Much of the conservation policy for Madagascar's rare, endemic tortoises has been based on limited biological and ecological data (Mittermeier et al., 2008) and the population size and density of $P$. arachnoides have never been rigorously estimated. The current study provides baseline data for the population size and density of the remaining wild population of $P$. arachnoides, using a distance sampling technique.

\section{Study area}

The biodiverse, dry coastal forests are unique to south-west Madagascar (Phillipson, 1996; Raxworthy \& Nussbaum, 2000; Seddon et al., 2000). Spider tortoises are habitat specialists, typically favouring areas of $<40 \%$ canopy cover (Walker et al., 2007). Walker (2010) and Walker et al. (in press) used high-resolution satellite imagery to establish areas within the suspected historical extent of occurence (Bour, 1981) of the species where suitable habitat still exists and then undertook time-dependent searches along transects to establish the presence or absence of remaining tortoise populations. From these data the area of the 
TABLE 1 Current known range of the three subspecies of the spider tortoise Pyxis arachnoides in Madagascar and the intergrades between them (Fig. 1), with the subpopulations indicated by the letters A-E, which correspond to the locations labelled in Fig. 1, and known total range of each subspecies or intergrade population, the source of these data, and the number of transects used to survey each subspecies and intergrade population and the years in which the surveys took place.

\begin{tabular}{|c|c|c|c|c|c|}
\hline Subspecies & $\begin{array}{l}\text { No. of } \\
\text { subpopulations }\end{array}$ & Range $\left(\mathrm{km}^{2}\right)$ & Source & $\begin{array}{l}\text { No. of } \\
\text { transects }\end{array}$ & Year of survey \\
\hline P. a. brygooi (A) & 3 & 499.6 & $\begin{array}{l}\text { Walker (2010), Walker et al. } \\
\text { (in press), Rhodin et al. (2011) }\end{array}$ & 13 & 2009 \\
\hline $\begin{array}{l}\text { P. a. brygooi/P. a. arachnoides } \\
\text { intergrades (B) }\end{array}$ & 1 & 99.7 & Walker et al. (in press) & 4 & 2009 \\
\hline P. a. arachnoides $(\mathrm{C})$ & 1 & $1,029.1$ & Walker et al. (in press) & 22 & 2010 \\
\hline $\begin{array}{l}\text { P. a. arachnoides/ } \\
\text { P. a. oblonga (D) }\end{array}$ & 1 & 267.0 & Walker et al. (in press) & 6 & 2010 \\
\hline P. a. oblonga $(\mathrm{E})$ & 2 & 568.5 & Walker et al. (in press) & 19 & $2010 / 2011$ \\
\hline Total & 8 & $2,468.8$ & & 64 & \\
\hline
\end{tabular}

fragments of remaining habitat supporting tortoises was calculated using a geographical information system (Walker, 2012), to give an accurate depiction of the remaining area of occupancy of the species.

$P$. arachnoides is extant in eight areas of forest comprising a total area of $2,463.8 \mathrm{~km}^{2}$ (Walker, 2010; Walker et al., in press; Table 1, Fig. 1). There are three subspecies (Chiari et al., 2005; Pedrono, 2008) and two zones of intergradation between these subspecies (Walker, 2010; Rhodin et al., 2011; Walker et al., in press). P. a. brygooi occupies the north of the species' range, comprising three fragmented populations north of the Manombo River, $P$. a. arachnoides occupies the range south of the Onilahy River to c. $30 \mathrm{~km}$ north of the Linta River (Fig. 1), and $P$. a. oblonga occupies the southernmost extent of the range around Cap Sainte Marie, with a further population stretching $70 \mathrm{~km}$ east of the Manambovo River through the coastal dunes to c. $70 \mathrm{~km}$ east of the Manambovo River (Walker, 2010; Walker et al., in press; Fig. 2). The two small intergrade populations are found within the transitional zones between $P$. a. brygooi and $P$. a. arachnoides (Walker, 2010) and between the ranges of $P$. a. arachnoides and P. a. oblonga (Walker et al., in press; Fig. 1).

\section{Methods}

\section{Distance sampling}

Line transect distance sampling is a widely used method for estimating the density and/or abundance of biological populations (Thomas et al., 2010) and has been widely applied to an array of taxa (Newey et al., 2003; Rivera-Milan et al., 2004; Jathanna et al., 2008), including southern Madagascar's two other dry forest tortoise species P. planicauda and Astrochelys radiata (O'Brien et al., 2003; Leuteritz et al., 2005; Young et al., 2008). Census techniques must be tailored to the study species (Krebs, 1999;
Southwood \& Henderson, 2000) and we took into account the ecological characteristics of $P$. arachnoides, surveying when the species was most active.

The statistical routine used for analysing line transect data obtained by distance sampling is based on Fourier analysis (Burnham et al., 1980; Akin, 1998), the accuracy of which depends on four assumptions: (1) surveyed objects directly on the line (at zero distance) will not be missed (i.e. $g(0)=1),(2)$ objects are fixed at the initial sighting position (i.e. they do not move rapidly upon detection and are not counted more than once), (3) distances are measured exactly, and (4) all sightings are independent (Burnham et al., 1980). Tortoises lend themselves to this method of estimation by not violating these key assumptions (Burnham et al., 1980; Akin, 1998; Leuteritz et al., 2005). However, $P$. arachnoides aestivates seasonally, during the dry season from May to November (Walker et al., 2007), and also daily during the warmest part of the day, between December and April when the species is otherwise at its most active (Walker et al., 2007; Walker, 2012). Therefore, if surveys are undertaken at inappropriate times of the day and/or year, the first and/or fourth assumption will be violated.

\section{Field techniques}

Sixty-four transects were surveyed across the species' range (Walker, 2010; Walker et al., in press; Table 1; Fig. 1); 63 were $1,000 \mathrm{~m}$ in length and one was $600 \mathrm{~m}$. Field work was during January and February in either 2009, 2010 or 2011, during the annual period of highest tortoise activity (Walker et al., 2007; Pedrono, 2008). The species is crepuscular (Walker et al., 2007; Walker, 2012) and therefore surveying was limited to the cooler parts of the day: 6.30-10.30 and 15.3018.30 (Walker et al., 2007).

Two observers traversed each transect, walking side by side on an easterly bearing using the tracking function of a 


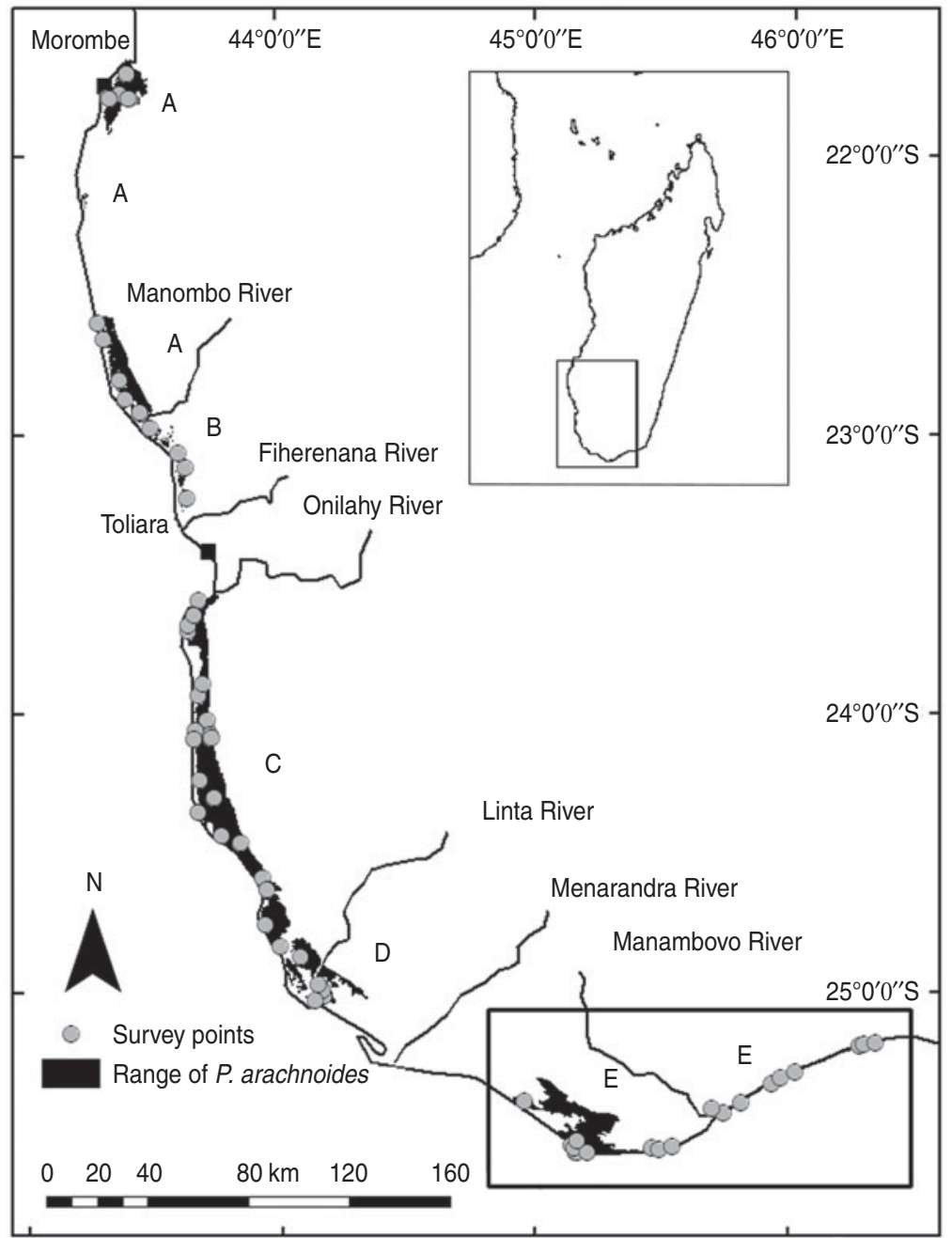

Fig. 1 The current known area of occurence of the three subspecies of the spider tortoise Pyxis arachnoides in eight areas of forest (Table 1 ; Walker, 2010; Walker et al., in press) and the locations of the 64 survey transects. A, three subpopulations of $P$. a. brygooi; $\mathrm{B}$, one subpopulation of $P$. a. brygooi/P. a. arachnoides intergrades; $\mathrm{C}$, one subpopulation of $P$. a. arachnoides; $\mathrm{D}$, one subpopulation of P. a. arachnoides/P. a. oblonga intergrades; E, two subpopulations of $P$. a. oblonga. The rectangle on the inset indicates the location of the main figure in south-west Madagascar. global positioning system to measure the distance covered. The surveyors searched carefully for tortoises on their respective side of the transect line and directly in front them. The mean time to traverse the $1,000 \mathrm{~m}$ transects was $34.7 \pm$ SD 5.1 minutes (not including the time spent stationary when tortoises were detected), with time dependent upon terrain and density of the vegetation. Upon encountering a tortoise the perpendicular distance from the centre of the transect line (where the observer was standing) was measured in $\mathrm{cm}$ to the middle of the carapace of the point of first detection for each tortoise, using a $15-\mathrm{m}$ retractable steel tape measure. Each tortoise was marked using a small dot of nail polish on the top of the carapace, to avoid duplicate counting.

\section{Data analysis}

Using Distance v. 5.0 (Thomas et al., 2010) a conventional distance sampling model was developed using the line transect data, comprising 109 tortoise records, of all size classes, across the transects. The probability of detection was modelled as a function of observed distance from the transect line using robust, semi-parametric methods. The perpendicular distance data for the 109 tortoises were examined in a histogram of 16 intervals of equal width (Laake, 1978), to investigate any responsive movement to the observer and clumping of observations (Fig. 3). No strong evidence of evasive movement was detected but there was clumping at $151-300 \mathrm{~cm}$ from the centre line and at zero distance $(<50 \mathrm{~cm}$; Fig. 3$)$. A quantile-quantile plot analysis indicated heaping in areas of the detection function, possibly as a result of inconsistent detection further from the centre line because of the small size of the species (adult mean straight carapace length $169 \pm$ SD $23.3 \mathrm{~mm}$; Walker et al., 2007), its cryptic behaviour and variations in habitat complexity (Best, 1981; Verner, 1985). It was therefore necessary to truncate at $700 \mathrm{~cm}$ from the centre line and transform the data into automatically adjusted intervals using the data filter function to gain a shoulder at zero distance (Fig. 4) and improve model robustness (Thomas et al., 2010). The following models, considered to be general and robust (Leuteritz et al., 2005; Young et al., 2008; Thomas et al., 2010), were considered: 


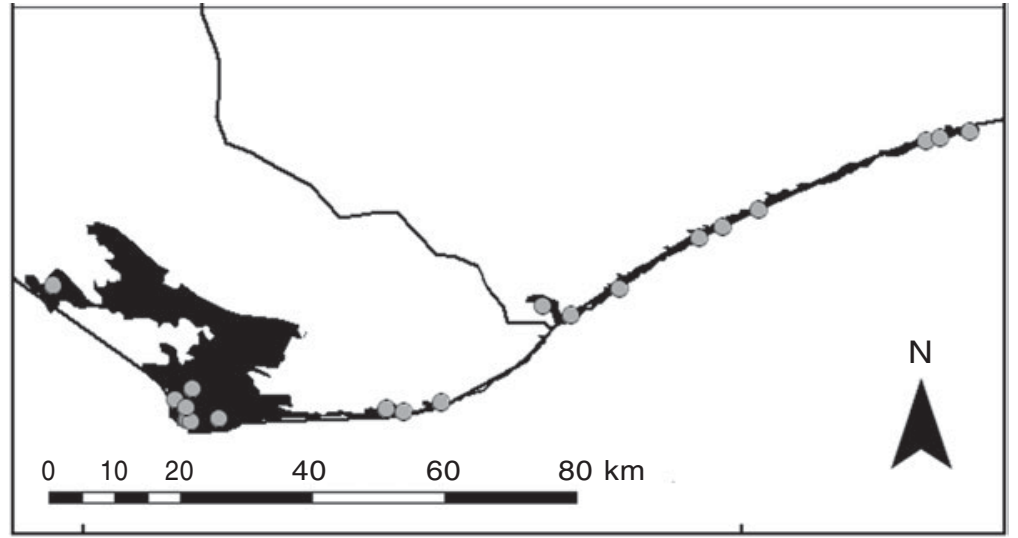

FIG. 2 Range of P. a. oblonga (the rectangle in Fig. 1), showing the narrow area occupied in the eastern part of its range as a result of habitat loss, which has forced the tortoises to occupy coastal sand dunes.

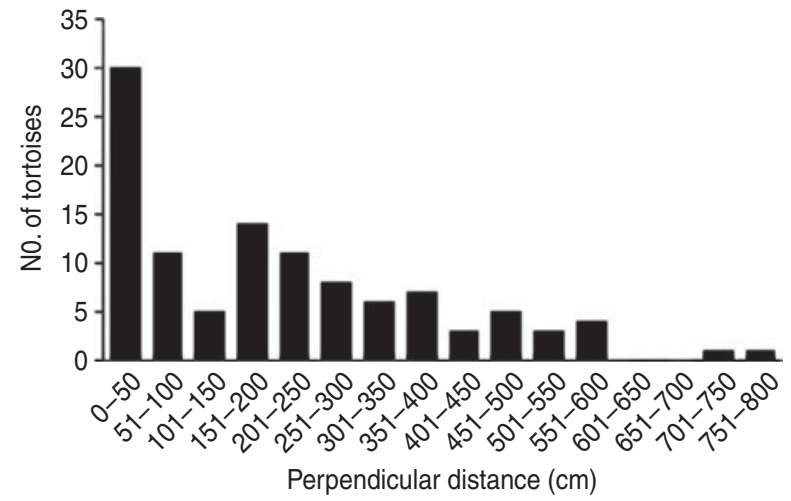

FIG. 3 A graphical representation of the raw distance sampling data showing the number of tortoises recorded in each $50 \mathrm{~cm}$ interval from the centre of the transect line. Heaping of the data can be seen at $151-300 \mathrm{~cm}$ and a spike at zero distance, results of the small size of the species and the influence of variations in habitat complexity on detection probability.

uniform/cosine (Burnham et al., 1980), uniform/simple polynomial (Anderson \& Pospahala, 1970), half-normal/ hermite polynomial and hazard-rate/simple polynomial (Buckland, 1985). Model fit was assessed using Akaike's information criterion (AIC), trading off the bias of simple models against the higher variance of more complex models (Burnham \& Anderson, 2002), and fit was tested using a $\chi^{2}$ goodness-of-fit test.

\section{Results}

The half-normal + hermite polynomial adjustment model proved a good fit to the data $\left(\chi^{2}=1.10, \mathrm{df}=3.00, \mathrm{P}=0.78\right)$ within the conventional distance sampling model. This adjustment model supported the lowest $\triangle$ AIC values (Table 2). The model's $15.2 \%$ coefficient of variation fell within the targeted level of precision $(<20 \%)$ suggested by Thomas et al. (2010). The mean tortoise density across its range was estimated to be $226.9 \mathrm{~km}^{-2}$ ( $95 \%$ confidence interval, CI, 168.1-306.3; Table 2). Using this density and the area of the known total range the total population size was

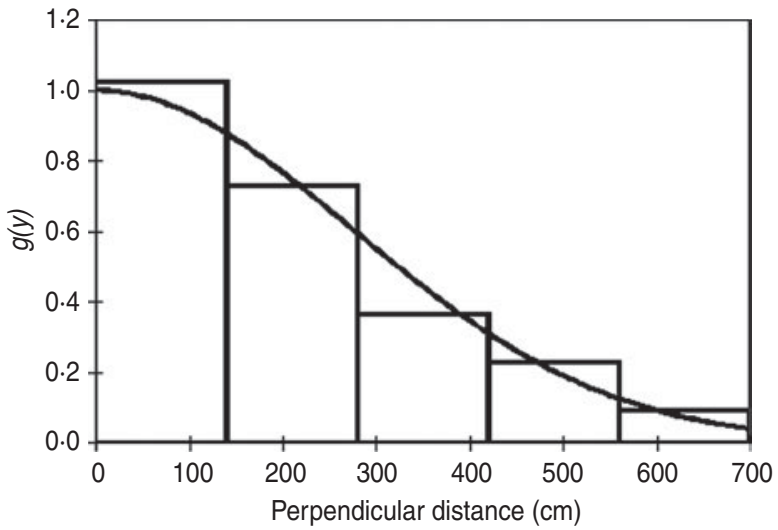

FIG. 4 Detection probability $g(y)$ for $P$. arachnoides after truncation of the data (Fig. 3) at $700 \mathrm{~cm}$ from the centre line and transformation into automatically adjusted intervals, using Distance.

estimated to be 664,980 tortoises ( $95 \%$ CI $492,680-897,550$; Table 2). Detection of tortoises fell dramatically with increasing distance from the centre of the transect line, as indicated by the effective strip half width of $340.7 \mathrm{~cm}$ (Fig. 4); i.e. it was difficult to detect tortoises $>3 \mathrm{~m}$ away from the centre line of the transect.

\section{Discussion}

Distance sampling is widely regarded as the most effective method for estimating the density and population of tortoises in dry forest environments (Hailey \& Willemsen, 2000; Anderson et al., 2001; Young et al., 2008). Leuteritz et al. (2005) compared distance sampling with the LincolnPetersen mark recapture technique (Greenwood, 1996) and concluded that the latter method was prone to overestimation when applied to the A. radiata population in south-west Madagascar. The half-normal model that we used is known to perform well with data that show a rapid fall in detection (Newey et al., 2003; Thomas et al., 2010), as shown in Fig. 3. This model works well for data collected on cryptic animals that inhabit areas of thick and patchy 
TABLE 2 Each of the four Distance models used to estimate the total population of spider tortoises, with corresponding $\Delta$ AIC and $\%$ coefficient of variation (\% CV), and estimated mean density per $\mathrm{km}^{2}$ and population size (both with $95 \% \mathrm{CI}$ ).

\begin{tabular}{lllll}
\hline Model & $\Delta \mathrm{AIC}$ & $\% \mathrm{CV}$ & Density, $\mathrm{km}^{-2}(95 \% \mathrm{CI})$ & Population size (95\% CI) \\
\hline Uniform + cosine & 1.23 & 13.82 & $209.4(159.3-275.2)$ & $613,570(466,740-806,590)$ \\
Uniform + simple polynomial & 2.87 & 10.44 & $247.4(178.1-343.8)$ & $725,100(512,830-1,000,750)$ \\
Half-normal + hermite polynomial & 0.00 & 15.23 & $226.9(168.1-306.3)$ & $664,980(492,680-897,550)$ \\
Hazard rate + simple polynomial & 1.39 & 12.15 & $231.6(163.2-328.7)$ & $678,600(478,110-963,160)$ \\
\hline
\end{tabular}

vegetation cover (Rivera-Milan et al., 2004), such as P. arachnoides.

All previous studies detailing the density of this species lacked spatial resolution and were confined to geographically small areas. Jesu \& Schimmenti (1995) and Walker et al. (2007) reported densities for $P$. a. arachnoides of $>3.0$ and $4.6 \pm \mathrm{SD} 1.6 \mathrm{ha}^{-1}$, respectively, in the Anakao region during the same time of year as our surveys, using sweep searches or simple belt transects. Pedrono (2008) observed densities of $>16 \mathrm{ha}^{-1}$ using sweep searches in areas of good habitat. Our results, however, suggest that the mean density across the species' remaining range is lower, at $2.3 \mathrm{ha}^{-1}$ (Table 2).

Pedrono (2008) speculated there were 2-3 million $P$. arachnoides and Randriamahazo et al. (2007) estimated 282,000, neither using a distance model. Randriamahazo et al.'s (2007) estimate was based on data from one isolated area (Cap Sainte Marie Special Reserve), using incidental sightings of $P$. a. oblonga recorded by Luteritiz et al. (2005) during their study of $A$. radiata. Our figure of 664,980 falls between these two estimates. Comparison with other small tortoise species of arid environments is difficult as the appropriate data are not available. Young et al. (2008), however, reported a total population of c. 28,00o P. planicauda, sparsely distributed (0.4 ha $\left.{ }^{-1}\right)$ across its narrow extent of occurence.

The range of $P$. arachnoides once spanned at least $555 \mathrm{~km}$ of coastline (Pedrono, 2008). The dry coastal forests of south-west Madagascar are, however, one of the country's most threatened terrestrial habitats, with habitat loss of $1.2 \%$ per year (Harper et al., 2007). This loss has resulted in severe fragmentation of the remaining area of occupancy of $P$. arachnoides (Walker, 2010; Walker et al., in press). As a result the population size is possibly $<30 \%$ of historical figures and could be less if the density of existing populations has been reduced by collection pressure and habitat degradation. Habitat degradation is a wide-ranging conservation threat for the remaining populations of $P$. arachnoides. Aponte et al. (2003) demonstrated that habitat degradation in South America can result in altered age structure, population density and growth rates of Chelonoidis carbonaria. The effects of habitat degradation and subsequent fragmentation of the spider tortoise's range may increase in the near future as a result of the proposal to extract mineral sand from south-west Madagascar (Sarrasin, 2006). This mining operation could affect $18 \%$ of the remaining range of the spider tortoise (Walker et al., in press).

The Système des'Aires Protégées de Madagascar has recently increased Madagascar's protected area threefold (Rabearivony et al., 2010). Several new protected areas have been established within the coastal dry forest, previously the least represented ecoregion within the country's protected area network (Fenn, 2003). Currently $73.5 \%$ of the remaining area of occupancy of $P$. arachnoides falls within existing or proposed protected areas (Walker et al., in press). However, with the exception of the Mikea Forest National Park and the extension to Tsimanampesotsa National Park, all new protected areas are IUCN category III, V and VI multipleuse protected areas (but see the critique of Gardner, 2011), co-managed by local community associations (WWF, unpubl. data). P. arachnoides may not receive complete protection from habitat destruction and poaching under such a management regime.

Currently, habitat loss resulting from subsistence agriculture and fuelwood harvesting is probably the greatest driver of the decline of the spider tortoise (Pedrono, 2008). It is important therefore to address the socio-economic and cultural issues causing local communities to harvest timber from the coastal dry forests. Such matters can only be addressed through targeted poverty alleviation and conservation programmes. Several NGOs in the region are engaged in livelihood generation projects, habitat restoration and community-based tortoise conservation projects (Rafeliarisoa et al., 2010; WWF, 2010). A project is underway within the range of $P$. a. brygooi to provide local communities within the Velondriake locally-managed marine area in south-west Madagascar with reproductive health and family planning (Harris et al., 2012), and this could alleviate local human population pressure on tortoise habitat. However, these projects are limited in their geographical scope and most areas within the region lack initiatives to diminish the heavy reliance of communities on natural resources.

\section{Acknowledgements}

This work was funded by the EAZA/Shell Shock Turtle Conservation Fund, the Turtle Survival Alliance, the Royal Geographical Society, the British Chelonia Group, the Mohamed Bin Zayed Species Conservation Fund, 
the Leicester Tortoise Society and the Chelonian Research Foundation. Logistical, technical and field support and advice were provided by Inge Smith, Solonombana Vitantsoa, Alice Ramsay, Al Harris, Eddie Louis, Brian Horne, Julien Bréchard, Richard Razafimanatsoa, Jean Caude Rakotoniaina, Blue Ventures Conservation, the Madagascar Biodiversity Partnership, Madagascar Institut pour la Conservations des Ecosystèmes Tropicaux, Ministère de l'Environnement et de Forêts, Madagascar National Parks and the University of Antananarivo, Mike Gillman, Justin Gerlach, Mandy Dyson and Ross Sinclair. We thank the coastal forest communities for allowing access to community-owned land. Ken Nussear, Miguel Pedrono, Charlie Gardner, Al Harris, Christina Castellano, Niqi Cummings and two anonymous referees provided useful comments.

\section{References}

AкIN, J.A. (1998) Fourier series estimation of ground skink population density. Copeia, 2, 519-522.

Anderson, D.R., Burnham, K.P., Lubow, B.C., Thomas, L., Corn, P.S., Medica, P.A. \& Marlow, R.W. (2001) Field trials of line transect methods applied to estimation of desert tortoise abundance. Journal of Wildlife Management, 65, 583-597.

Anderson, D.R. \& Pospahala, R.S. (1970) Correction of bias in belt transects of immotile objects. Journal of Wildlife Management, 34, 141-146.

Aponte, C., Barreto, G.R. \& Terborgh, J. (2003) Consequences of habitat fragmentation on age structure and life history in a tortoise population. Biotropica, 35, 550-555.

BEST, L.B. (1981) Seasonal changes in detection of individual bird species. Studies in Avian Biology, 6, 252-261.

Bour, R. (1981) Etude systématique du genre endémique Malgache Pyxis Bell, 1827 (Reptilia, Chelonii). Bulletin Mensuel de la Société Linnéenne de Lyon, 50, 154-176.

Brooks, T.M., Mittermeier, R.A., da Fonseca, G.A.B., Gerlach, J., Hoffmann, J., Lamoreux, F.J. et al. (2006) Global biodiversity conservation priorities. Science, 313, 58-61.

Buckland, S.T. (1985) Perpendicular distance models for the line transect sampling. Biometrics, 41, 177-195.

Burnham, K.P. \& Anderson, D.R. (2002) Model Selection and Multimodel Inference: A Practical Information-Theoretic Approach, 2nd edition. Springer-Verlag, New York, USA.

Burnham, K.P., Anderson, D.R. \& LaAke, J.L. (1980) Estimation of density from line transect sampling of biological populations. Wildlife Monographs, 72, 1-202.

Chiari, Y., Thomas, M., Pedrono, M. \& Veites, D.R. (2005) Preliminary data on genetic differentiation within the Madagascar spider tortoise, Pyxis arachnoides (Bell, 1827). Salamandra, 41, 35-43.

Fenn, M. (2003) The spiny forest ecoregion. In The Natural History of Madagascar (eds S.M. Goodman \& J.P. Benstead), pp. 1525-1530. University of Chicago Press, Chicago, USA.

GARDNER, C.J. (2011) IUCN management categories fail to represent new, multiple-use protected areas in Madagascar. Oryx, 45, 336-346.

Goodman, S.M. \& BensteAd, J.P. (2005) Updated estimates of biotic diversity and endemism for Madagascar. Oryx, 39, 73-78.

Greenwood, J.J.D. (1996) Basic techniques. In Ecological Census Techniques: A Handbook (ed. W.J. Sutherland), pp. 11-109. Cambridge University Press, Cambridge, UK.
Hailey, A. \& Willemsen, R.E. (2000) Population density and adult sex ratio of the tortoise Testudo hermanni in Greece: evidence for intrinsic population regulation. Journal of Zoology, 251, 325-338.

Harper, G., Steininger, M., Tucker, C., Juhn, D. \& Hawkins, F. (2007) Fifty years of deforestation and forest fragmentation in Madagascar. Environmental Conservation, 34, 325-333.

Harris, A., Mohan, V., Flanagan, M. \& Hill, R. (2012) Integrating family planning service provision into community-based marine conservation. Oryx, 46, 179-186.

Jathanna, D.N., Kumar, S. \& Karanth, K.U. (2008) Measuring Indian giant squirrel Ratufa indica abundance in southern India using distance sampling. Curent Science, 95, 885-888.

Jesu, R. \& Schimmenti, G. (1995) A preliminary study on the status of a population of Malagasy spider tortoise Pyxis arachnoides Bell, 1927 from SW Madagascar. In International Congress of Chelonian Conservation, 6-10 July 1995 (ed. B. Devaux), pp. 144-147. SOPTOM, Gonfaron, France.

Krebs, C.J. (1999) Ecological Methodology, 2nd edition. Addison Welsey Longman, Menlo Park, USA.

LAAKE, P. (1978) An evaluation of synthetic estimates of employment. Scandinavian Journal of Statistics, 5, 57-60.

Leuteritz, T.E.J., Lamb, T. \& Limberaza, J.C. (2005) Distribution, status and conservation of radiated tortoises (Geochelone radiata) in Madagascar. Biological Conservation, 124, 451-461.

Leuteritz, T.E.J., Randriamahazo, H. \& Lewis, R. (2008) Pyxis planicauda. In IUCN Red List of Threatened Species v. 2011.2. Http:// www.iucnredlist.org [accessed 19 March 2012].

Leuteritz, T.E.J. \& Walker, R. (2008) Pyxis arachnoides. In IUCN Red List of Threatened Species v. 2011.2. Http://www.iucnredlist.org [accessed 19 March 2012].

Mittermeier, R.A., Rhodin, A.G.J., Randriamahazo, H., Lewis, R.E., van Dijk, P.P., Hudson, R. \& Rioux Paquette, S. (2008) Vision sokatra gasy-Madagascar turtle vision. Turtle and Tortoise Newsletter, 12, 7-9.

Newey, S., Bell, M., Enthoven, S. \& Thirgood, S. (2003) Can distance sampling and dung plots be used to assess the density of mountain hares Lepus timidus? Wildlife Biology, 9, 185-192.

O’Brien, S., Emahalala, E.R., Beard, V., Rakotondrainy, R.M., Reid, A., Raharisoa, V. \& Coulson, T. (2003) Decline of the Madagascar radiated tortoise (Geochelone radiata) due to overexploitation. Oryx, 37, 338-343.

Pedrono, M. (2008) The Tortoises and Turtles of Madagascar. Natural History Publications (Borneo), Kota Kinabalu, Malaysia.

Phillipson, P.B. (1996) Endemism and non-endemism in the flora of southwest Madagascar. In Biogéographie de Madagascar (ed. W.R. Lourenco), pp. 125-136. Editions de l'Orstom, Paris, France.

Rabearivony, J., Thorstrom, R., Rene de Roland, L.A., Rakotondratsima, M., Andriamalala, T.R.A., Sam, T.S. et al. (2010) Protected area surface extension in Madagascar: do endemism and threatened species remain useful criteria for site selection? Madagascar Conservation \& Development, 5, 35-47.

Rafeliarsoa, T.H., Shore, G.D., McGuire, S.M. \& Louis, Jr, E.E. (2010) Innovative solutions to conservation challenges for the radiated tortoise (Astrochelys radiata) project at Lavavolo Classified Forest, Madagascar. Turtle Survival Magazine, August 2010, 64-66.

Randriamahazo, H., Traylor-Holzer, K., Leus, K. \& Byers, H.O. (2007) Population and Habitat Viability Assessment Workshop for Endemic Tortoise Species in Madagascar Geochelone radiata (Madagascar Radiated Tortoise) Pyxis arachnoides (Spider Tortoise). IUCN/Species Survival Commission Conservation Breeding Specialist Group, Apple Valley, USA.

Raxworthy, C. \& Nussbaum, R. (200o) Extinction and extinction vulnerability of amphibians and reptiles in Madagascar. Amphibian \& Reptile Conservation, 2, 15-23. 
Rhodin, A.G.J., Walde, A.D., Horne, B.D., van Dijk, P.P., Blanck, T. \& Hudson, R. (eds) (2011) Turtles in Trouble: The World's 25+ Most Endangered Tortoises and Freshwater Turtles-2011. IUCN/Species Survival Commission Tortoise and Freshwater Turtle Specialist Group, Lunenburg, USA.

Rivera-Milan, F.F., Zaccagnini, M.E. \& Canavelli, S.B. (2004) Field trials of line-transect surveys of bird carcasses in agroecosystems of Argentina's pampas region. Wildlife Society Bulletin, $32,1219-1228$.

SARRASIN, B. (2006) The mining industry and the regulatory framework in Madagascar: some developmental and environmental issues. Journal of Cleaner Production, 14, 388-396.

Seddon, N., Tobias, J., Yount, J.W., Ramanampamonjy, J.R., Butchart, S. \& Randrianizahana, H. (2000) Conservation issues and priorities in the Mikea Forest of south-west Madagascar. Oryx, 34, 287-304.

Southwood, R. \& Henderson, P.A. (2000) Ecological Methods. Blackwell Science, London, UK.

Thomas, L., Buckland, S.T., Rexstad, E.A., Laake, J.L., StrindberG, S., Hedley, S.L. et al. (2010) Distance software: design and analysis of distance sampling surveys for estimating population size. Journal of Applied Ecology, 47, 5-14.

Verner, J. (1985) Assessment of counting techniques. In Current Ornithology, 2nd edition (ed. R.F. Johnston), pp. 247-302. Plenum Press, New York, USA.

WALKer, R.C.J. (2010) The decline of the northern Madagascar spider tortoise (Pyxis arachnoides brygooi). Herpetologica, 6, 411-417.

WALKER, R.C.J. (2012) A critical evaluation of field survey methods for establishing the range of a small, cryptic tortoise (Pyxis arachnoides). Herpetological Journal, 22, 7-12.

Walker, R.C.J., Gardner, J.C., Rafeliarisoa, T.H., Smith, I. \& Razafimanatsoa, R. (in press) Conservation of the Madagascar spider tortoise (Pyxis arachnoides) amid changing land use policy: assessing the spatial coincidence of relict populations with protected areas and mining concessions. In Turtles on the Brink in Madagascar: Proceedings of Two Workshops on Status and
Conservation of Malagasy Tortoises and Freshwater Turtles (eds C.M. Castellano, H. Randriamahazo, R.E. Lewis, R.A. Mittermeier, R. Hudson \& A.G.J. Rhodin). Chelonian Research Monographs, Lunenburg, USA.

Walker, R.C.J., Rix, C.E. \& Woods-Ballard, A.J. (2004) The export of the endangered Madagascar spider tortoise Pyxis arachnoides to support the exotic pet trade. Herpetological Bulletin, 90, 2-9.

Walker, R.C.J., Woods-Ballard, A.J. \& Rix, C.E. (2007) Population density and seasonal activity of the threatened Madagascar spider tortoise Pyxis arachnoides arachnoides of the southern dry forests; South West Madagascar. African Journal of Ecology, 46, 67-73.

Wilmé, L., Goodman, S.M. \& Ganzhorn, J.U. (2006) Biogeographic evolution of Madagascar's microendemic biota. Science, 312, 1063-1065.

WWF (2010) Programme d'actions de WWF sur les tortues terrestres endémiques du sud-ouest de Madagascar: Astrochelys radiata et Pyxis arachnoides 2010-2015. Unpublished Report. WWF, Antananarivo, Madagascar.

Young, R.P., Toto Volahy, A., Bourou, R., Lewis, R., Durbin, J. \& FA, J.E. (2008) Estimating the population of the Endangered flat-tailed tortoise Pyxis planicauda in the deciduous, dry forest of western Madagascar: a monitoring baseline. Oryx, 42, $252-258$.

\section{Biographical sketches}

RYAN C.J. WALKer is a freelance wildlife biologist currently contracted by several NGOs and environmental consultancies. He is also continuing his research on the biogeography and conservation management of $P$. arachnoides. Tsilavo H. Rafeliarisoa is a herpetologist and geneticist. He is currently researching the biogeography and population genetics of the Critically Endangered radiated tortoise Astrochelys radiata. 